\title{
JENIS JENIS NARKOBA
}

\author{
D \\ I \\ S \\ $\mathbf{U}$ \\ S \\ $\mathbf{U}$ \\ $\mathbf{N}$
}

\section{OLEH :}

NAMA : Tiara Angelia KELAS : X MIA 2 


\section{KATA PENGANTAR}

Segala puji bagi Tuhan yang telah memberikan kami kemudahan sehingga kami dapat menyelesaikan makalah ini dengan tepat waktu. Tanpa pertolongan-Nya tentunya kami tidak akan sanggup untuk menyelesaikan makalah ini dengan baik.

Penulis mengucapkan syukur kepada Tuhan atas limpahan nikmat sehat-Nya, baik itu berupa sehat fisik maupun akal pikiran, sehingga penulis mampu untuk menyelesaikan pembuatan makalah sebagai tugas dari mata pelajaran PENJASORKES dengan judul "Jenis jenis Narkoba".

Penulis tentu menyadari bahwa makalah ini masih jauh dari kata sempurna dan masih banyak terdapat kesalahan serta kekurangan di dalamnya. Untuk itu, penulis mengharapkan kritik serta saran dari pembaca untuk makalah ini, supaya makalah ini nantinya dapat menjadi makalah yang lebih baik lagi. Kemudian apabila terdapat banyak kesalahan pada makalah ini penulis mohon maaf yang sebesar-besarnya.

Penulis juga mengucapkan terima kasih kepada semua pihak khususnya kepada guru Penjas kami yang telah membimbing dalam menulis makalah ini.

Demikian, semoga makalah ini dapat bermanfaat. Terima kasih.

Medan, 20 Mei 2020 


\section{DAFTAR ISI}

KATA PENGANTAR ................................................................................... $\mathrm{i}$

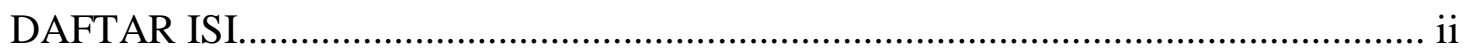

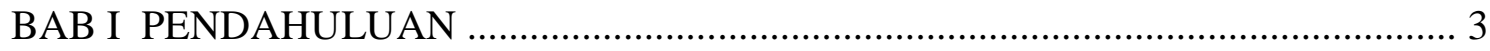

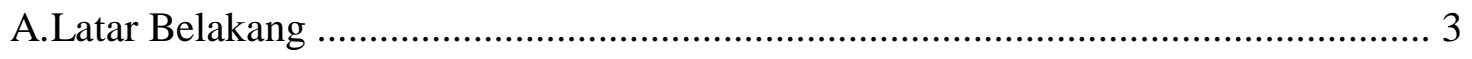

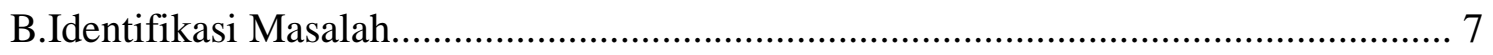

C. Batasan Masalah.......................................................................................... 7

D. Rumusan Masalah........................................................................................ 7

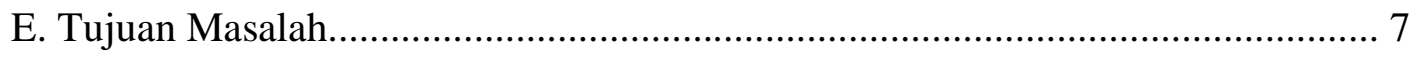

BAB II PEMBAHASAN............................................................................... 8

A. Pengertian Narkoba ................................................................. 8

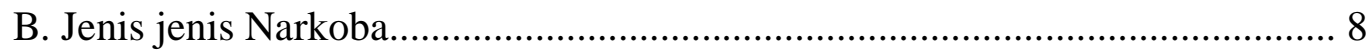

C. Bahaya dan Dampak Narkoba pada Hidup dan Kesehatan............................ 9

D. Pencegahan Penyalahgunaan Narkotika.............................................. 11

E. Pencegahan Penyalahgunaan Narkoba................................................12

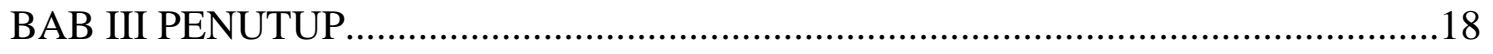

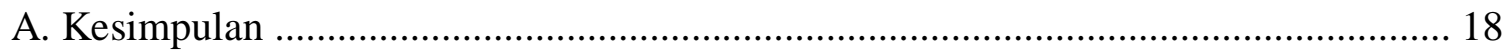

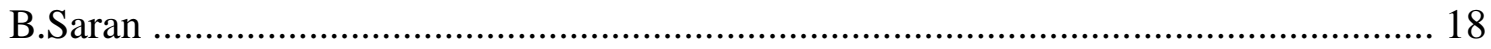

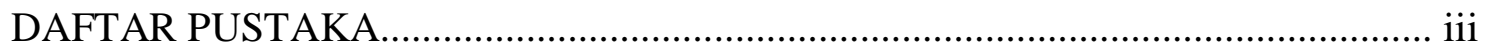




\section{BAB 1}

\section{PENDAHULUAN}

\section{A. Latar Belakang}

Narkoba merupakan singkatan dari Narkotika, Psikotropika dan zat adiktif lainnya BNN (2006). Narkoba pada awalnya digunakan untuk keperluan medis, pemakaiannya akan menjadi aman dan efektif apabila digunakan pada dosis tertentu, bentuk - bentuk tertentu dan juga pada waktu yang tepat. Narkoba menjadi disalahgunakan apabila digunakan untuk tujuan non medis seperti: mabuk, menurunkan berat badan dan menambah massa otot Anonymous (2006). Menurut Joewana dan Martono (2006) dibalik dampak negatifnya, penggunaan narkoba mampu untuk menimbulkan kesenangan dan juga perasaan -perasaan bahagia yang semu. Jika tidak, seseorang tidak akan mengambil resiko yang begitu besar untuk kehilangan pekerjaan, pendidikan, kesehatan dan lingkungan sosialnya. Efek yang ditimbulkan dari pemakaian narkoba adalah: hilangnya rasa kesepian, hilangnya perasaan perasaan negatif, halusinasi, euforia berlebihan, mampu menggendalikan situasi, terbebas dari kejaran waktu, meningkatkan semangat dan rasa percaya diri. Apabila narkoba dikonsumsi secara terus menerus dan berlebihan maka pemakai akan menjadi bergantung / adiksi pada zat tersebut. Ketergantungan narkoba ini akan menimbulkan efek - efek negatif pada fisik dan juga psikologis jika pemakaiannya dihentikan, contohnya seperti: rasa nyeri pada badan, kejang - kejang, gelisah, sulit tidur, takut air, cemas, mudah tersinggung, melakukan kekerasan dan cenderung untuk bunuh diri Joewana \& Martono (2006). Efek yang paling berbahaya dalam penyalahgunaan narkoba adalah menurunnya sistem kekebalan tubuh yang akan meningkatkan kemungkinan terjangkit virus HIV, hepatitis $\mathrm{C}$ bahkan sampai menyebabkan kematian (Anonymous, 2005). Pada saat ini penyalahgunaan narkoba pada kalangan remaja Indonesia menunjukan peningkatan. Berdasarkan survei nasional yang dilakukan oleh Badan Narkotika Nasional (BNN) yang berkerja sama dengan Pusat Penelitian Kesehatan Universitas Indonesia, pada tahun 2011 terdapat 2,2 persen atau sekitar 4 juta penduduk Indonesia yang menyalahgunakan narkoba. Dari jumlah tersebut 22 persen atau sekitar 880 ribu orang merupakan remaja yang masih berstatus sebagai pelajar dan mahasiswa(Anonymous, 2013). Dari data survei penyalahgunaan narkoba yang dilakukan BNN dan Universitas Indonesia pada tahun 2011 menyebutkan bahwa lokasi seperti Jawa Barat, Jawa Tengah, Aceh dan Kalimantan tengah angkanya relatif stabil bahkan khusus untuk daerah DKI Jakarta cenderung mengalami peningkatan. Responden yang mengikuti survei ini berimbang antara pria dengan wanita dengan kisaran umur antara 15 tahun sampai dengan 21 tahun yang masih berada dalam kelompok usia remaja. Hasil dari survei ini juga menyebutkan bahwa semakin tinggi tingkat pendidikan dan umur dari responden maka semakin tinggi juga penyalahgunaan terhadap narkoba. Angka penyalahgunaan lebih tinggi di kota dibandingkan dengan kabupaten dan lebih tinggi juga pada sekolah / perguruan tinggi swasta dibandingkan dengan yang lainnya (Nugroho, 2012). Salah satu contoh dari kasus penyalahgunaan narkoba dialami oleh ES yang merupakan siswa sekolah menengah pertama 
berumur 16 tahun. ES terpaksa harus mengikuti ujian nasional di kantor polisi karena sebelumnya tertangkap menyimpan narkotika golongan satu jenis ganja (Aziz, 2013). Kasus lain dari penyalahgunaan narkoba juga dialami oleh PA yang berumur 19 tahun dan FA yang berumur 16 tahun. Kedua siswi ini ditangkap oleh badan narkotika nasional karena kedapatan memiliki 2 gram sabu - sabu dan 14 butir ekstasi. Kedua pelajar ini positif mengkonsumsi narkoba dan diduga terlibat dari sindikat peredaran narkoba internasional (Belarminus, 2013). Santrock (2011) mendefinisikan remaja sebagai suatu masa peralihan dari masa anak - anak menuju masa dewasa yang dimulai dari usia 10 sampai 12 tahun dan berakhir pada usia 18 sampai 22 tahun. Perkembangan fisik, kognitif serta sosioemosi menjadi lebih matang pada usia remaja. Pada tahap ini pola berpikir remaja menjadi lebih abstrak dan idealistik, mereka berusaha untuk mengekspresikan diri dengan mencoba hal - hal yang baru dan mencoba mencari identitas diri yang sesuai dengan keinginan mereka. Berdasarkan teori Erikson (Santrock, 2011) pada tahap ini remaja berada pada fase identity versus identity confusion dimana mereka mulai melakukan percobaan pada berbagai karakter serta kepribadian yang tujuannya untuk mengetahui siapakah dirinya dan menemukan tujuan hidup mereka kedepannya. Pada usia ini remaja juga memiliki pemikiran bahwa orang lain memberikan perhatian yang amat besar terhadap karakteristik pribadi yang dimiliki oleh remaja tersebut. Remaja juga membentuk suatu keyakinan bahwa tidak ada seorangpun yang dapat memahami keunikan yang dimiliki oleh diri mereka (Santrock, 2003). Pada usia ini remaja mulai mencoba melepaskan diri dari orang tua. Mereka memiliki keinginan yang kuat untuk dapat mandiri dan memiliki tanggung jawab pribadi terhadap prilakunya sendiri (Santrock, 2011). Remaja juga lebih mengutamakan peran dari peer grup atau sahabat mereka daripada peran dari orang tua. Hal ini terjadi karena remaja memiliki suatu kebutuhan untuk membangun suatu hubungan dekat terhadap para sahabatnya untuk dapat merasakan kebersamaan dan ketenangan Bukowski dkk (dalam Santrock, 2011). Remaja juga menjadi lebih terbuka untuk menceritakan masalah pribadi kepada teman - temannya. Kebutuhan remaja akan intimasi membuat remaja berusaha melakukan sesuatu agar dapat diterima oleh kelompoknya. Prinstein (dalam Santrock, 2011) mengatakan bawa remaja cenderung akan menyesuaikan diri dengan kelompok pergaulannya apabila mereka tidak memiliki keyakinan terhadap identitas sosialnya. Jika remaja gagal untuk memenuhi kebutuhan ini maka mereka akan mengalami rasa kesepian dan juga penilaian terhadap dirinya sendiri juga akan berkurang Suliva ( Santrock, 2011). Namun untuk mencapai otonominya tersebut, remaja masih membutuhkan peran dari orang tua. Pada umumnya banyak orang tua menganggap bahwa remaja akan banyak mengalami kesulitan untuk beradaptasi pada usia remaja dan hanya sedikit orang tua yang dapat merasakan bahwa remaja memiliki dorongan yang kuat untuk bertemu dengan teman sebayanya, atau memiliki pikiran bahwa anak mereka yang menentukan keberhasilan dan kegagalannya dalam menjalani kehidupan. Orang tua ini sendiri memiliki peran vital terhadap proses perkembangan anak. Pengasuhan yang diberikan oleh orang tua kepada anak sudah dimulai sejak tahun pertama kehidupan si anak. Mengacu pada teori psikososial Erik Erikson, bahwa setiap individu memiliki kebutuhan - kebutuhan 
pada setiap tahapannya. Clemes (1995) mengatakan bahwa dua puluh tahun pertama dihabiskan oleh anak untuk belajar mengenai keterampilan, tanggung jawab, penilaian diri dan membangun rasa kepercayaan diri. Anak yang memasuki usia remaja akan membawa atribut - atribut tersebut untuk dapat beradaptasi dengan dunia orang dewasa. Pengasuhan yang diberikan orang tua akan membentuk suatu kepribadian serta kualitas pada diri anak anak mereka. Perkembangan positif akan diperoleh anak apabila mereka juga mendapatkan pengasuhan yang positif dari orang tua mereka. Pengasuhan yang baik dengan memberikan kasih sayang, perhatian dan juga aturan - aturan yang tidak mendominasi akan menciptakan rasa kepercayaan pada anak bahwa mereka diterima oleh lingkungannya. Tindakan tindakan yang akurat dari orang tua akan membantu anak untuk mencapai otonomi yang lebih matang dan tepat Laursen dkk (Santrock 2011). Menurut Baumrind (dalam Santrock, 2011) terdapat tiga jenis pola pengasuhan orang tua terhadap anak, yaitu: Pola asuh otoritarian merupakan jenis pola asuh dimana orang tua menerapkan peraturan yang harus dilakukan oleh anak dan mungkin memberikan hukuman yang keras Anak dengan pola asuh otoritarian akan membentuk sikap hormat dan taat pada orang tua, namun sisi negatif dari pola asuh otoritarian ini adalah anak akan membangun perasaan takut, cemas, tidak bahagia, inisiatif tidak terbentuk dan juga kurang dapat membangun komunikasi dengan baik. Pola asuh memanjakan merupakan pola asuh dimana orang tua selalu memberikan apa yang diinginkan oleh anak tanpa memberikan kontrol dan aturan yang jelas. Anak dengan pola asuh permisif akan lebih kreatif dan percaya diri, namun disamping itu anak dengan pola asuh ini cenderung kurang memiliki kontrol diri yang baik, mendominasi, kurang dapat menghormati dan tidak dapat menjalin hubungan yang baik dengan temannya. Pola asuh otoritatif lebih membuka kesempatan kepada anak untuk mandiri namun masih memberikan kontrol serta aturan terhadap anak. Anak dengan pola asuh otoritatif lebih percaya diri, memiliki pengendalian diri yang baik, mampu mengelola stress dan dapat bekerja sama dengan teman sebaya maupun orang - orang yang lebih tua. Beberapa analisa dan penelitian yang telah dilakukan sebelumnya menunjukan bahwa penyalahgunaan narkoba yang dilakukan oleh remaja memiliki kaitannya dengan hubungan yang dibentuk antara orang tua dengan anak. Analisis dari Jerald Bachman dkk pada tahun 2008 (Santrock, 2011) mengungkapkan bahwa keberhasilan dari pendidikan dasar yang didapatkan anak dari orang tua akan menekan kecenderungan seorang anak untuk merokok, mengkonsumsi alkohol serta melakukan penyalahgunaan narkoba. Penelitian yang dilakukan National Longitudinal Study terhadap 12.000 orang remaja mengenai kesehatan menemukan bahwa remaja yang tidak bertemu dengan orang tua mereka saat makan malam minimal lima hari seminggu secara signifikan menunjukkan peningkatan dalam hal konsumsi rokok, minuman beralkohol, berkelahi, melakukan aktivitas seksual dan menggunakan narkoba Council of Economic Advisors (Santrock, 2011). Brook dkk (Santrock, 2011) mengatakan bahwa konflik yang terjadi dalam tingkat tinggi serta berlangsung dalam waktu yang lama antara orang tua dan anak memiliki hubungannya dengan sejumlah masalah pada remaja seperti kabur dari rumah, putus sekolah, hamil di luar nikah dan melakukan penyalahgunaan narkoba. Martono \& 
Joewana (2006) mengatakan bahwa sejumlah remaja yang melakukan penyalahgunaan narkoba dan mengikuti terapi menunjukan tingkat stres yang besar, penilaian diri yang rendah serta hubungan keluarga yang tidak harmonis dan terlalu banyak meminta tuntutan. Berdasarkan dari uraian di atas maka dapat disimpulkan bahwa pengasuhan orang tua akan membentuk kepribadian seorang anak. Pengasuhan yang buruk / negatif akan membentuk kepribadian yang negatif juga pada anak. Dari kepribadian negatif ini maka akan meimbulkan potensi bagi remaja untuk dapat melakukan penyalahgunaan narkoba. Hal ini

membuat peneliti menjadi tertarik untuk melihat bagaimanakah pengasuhan yang diberikan oleh orang tua pada remaja yang melakukan penyalahgunaan narkoba.

\section{B. Identifikasi masalah}

Dari latar belakang yang ada, dapat diidentifikasi masalah yang terjadi sebagai berikut :

1. Jenis jenis narkoba

2. Pencegahannya

\section{Pembatasan masalah}

Makalah ini hanya membahas tentang jenis jenis narkoba Dan cara pencegahannya.

\section{Rumusan masalah}

Berdasarkan latar belakang masalah, maka dapat dirumuskan masalah sebagai berikut:

1. Apa saja jenis jenis narkoba yang di konsumsi masyarakat?

2. Bagaimana pencegahannya?

\section{E. Tujuan masalah}

1. Menjelaskan apa saja jenis jenis narkoba

2. Menjelaskan pencegahan narkoba di lingkungan masyarakat. 


\section{BAB II}

\section{PEMBAHASAN}

\section{A. Pengertian Narkoba (Narkotika dan Obat-obatan)}

Narkotika adalah zat atau obat baik yang bersifat alamiah, sintetis, maupun semi sintetis yang menimbulkan efek penurunan kesadaran, halusinasi, serta daya rangsang.

Sementara menurut UU Narkotika pasal 1 ayat 1 menyatakan bahwa narkotika merupakan zat buatan atau pun yang berasal dari tanaman yang memberikan efek halusinasi, menurunnya kesadaran, serta menyebabkan kecanduan.

Obat-obatan tersebut dapat menimbulkan kecanduan jika pemakaiannya berlebihan. Pemanfaatan dari zat-zat itu adalah sebagai obat penghilang nyeri serta memberikan ketenangan.

Penyalahgunaannya bisa terkena sanksi hukum. Untuk mengetahui apa saja jenis dan bahaya narkoba bagi kesehatan, simak ulasannya berikut ini.

\section{B. Jenis-jenis Narkoba (Narkotika dan Obat-obatan)}

Kandungan yang terdapat pada narkoba tersebut memang bisa memberikan dampak yang buruk bagi kesehatan jika disalahgunakan. Menurut UU tentang Narkotika, jenisnya dibagi menjadi menjadi 3 golongan berdasarkan pada risiko ketergantungan.

- Narkotika Golongan 1

Narkotika golongan 1 seperti ganja, opium, dan tanaman koka sangat berbahaya jika dikonsumsi karena beresiko tinggi menimbulkan efek kecanduan.

- Narkotika Golongan 2

Sementara narkotika golongan 2 bisa dimanfaatkan untuk pengobatan asalkan sesuai dengan resep dokter. Jenis dari golongan ini kurang lebih ada 85 jenis, beberapa diantaranya seperti Morfin, Alfaprodina, dan lain-lain. Golongan 2 juga berpotensi tinggi menimbulkan ketergantungan.

- Narkotika Golongan 3

Dan yang terakhir, narkotika golongan 3 memiliki risiko ketergantungan yang cukup ringan dan banyak dimanfaatkan untuk pengobatan serta terapi. 
Seperti yang sudah disebutkan di atas, ada beberapa jenis narkoba yang bisa didapatkan secara alami namun ada juga yang dibuat melalui proses kimia. Jika berdasarkan pada bahan pembuatnya, jenis-jenis narkotika tersebut di antaranya adalah:

- Narkotika Jenis Sintetis

Jenis yang satu ini didapatkan dari proses pengolahan yang rumit. Golongan ini sering dimanfaatkan untuk keperluan pengobatan dan juga penelitian. Contoh dari narkotika yang bersifat sintetis seperti Amfetamin, Metadon, Deksamfetamin, dan sebagainya.

- Narkotika Jenis Semi Sintetis

Pengolahan menggunakan bahan utama berupa narkotika alami yang kemudian diisolasi dengan cara diekstraksi atau memakai proses lainnya. Contohnya adalah Morfin, Heroin, Kodein, dan lain-lain.

- Narkotika Jenis Alami

Ganja dan Koka menjadi contoh dari Narkotika yang bersifat alami dan langsung bisa digunakan melalui proses sederhana. Karena kandungannya yang masih kuat, zat tersebut tidak diperbolehkan untuk dijadikan obat. Bahaya narkoba ini sangat tinggi dan bisa menyebabkan dampak buruk bagi kesehatan jika disalahgunakan. Salah satu akibat fatalnya adalah kematian.

\section{Bahaya dan Dampak Narkoba pada Hidup dan Kesehatan}

Peredaran dan dampak narkoba saat ini sudah sangat meresahkan. Mudahnya mendapat bahan berbahaya tersebut membuat penggunanya semakin meningkat. Tak kenal jenis kelamin dan usia, semua orang berisiko mengalami kecanduan jika sudah mencicipi zat berbahaya ini.

Meski ada beberapa jenis yang diperbolehkan dipakai untuk keperluan pengobatan, namun tetap saja harus mendapatkan pengawasan ketat dari dokter. Ada banyak bahaya narkoba bagi hidup dan kesehatan, di antaranya adalah:

- Dehidrasi

Penyalahgunaan zat tersebut bisa menyebabkan keseimbangan elektrolit berkurang. Akibatnya badan kekurangan cairan. Jika efek ini terus terjadi, tubuh akan kejang-kejang, muncul halusinasi, perilaku lebih agresif, dan rasa sesak pada bagian dada. Jangka panjang dari dampak dehidrasi ini dapat menyebabkan kerusakan pada otak. 
- Halusinasi

Halusinasi menjadi salah satu efek yang sering dialami oleh pengguna narkoba seperti ganja. Tidak hanya itu saja, dalam dosis berlebih juga bisa menyebabkan muntah, mual, rasa takut yang berlebih, serta gangguan kecemasan. Apabila pemakaian berlangsung lama, bisa mengakibatkan dampak yang lebih buruk seperti gangguan mental, depresi, serta kecemasan terus-menerus.

- Menurunnya Tingkat Kesadaran

Pemakai yang menggunakan obat-obatan tersebut dalam dosis yang berlebih, efeknya justru membuat tubuh terlalu rileks sehingga kesadaran berkurang drastis. Beberapa kasus si pemakai tidur terus dan tidak bangun-bangun. Hilangnya kesadaran tersebut membuat koordinasi tubuh terganggu, sering bingung, dan terjadi perubahan perilaku. Dampak narkoba yang cukup berisiko tinggi adalah hilangnya ingatan sehingga sulit mengenali lingkungan sekitar.

\section{- Kematian}

Dampak narkoba yang paling buruk terjadi jika si pemakai menggunakan obat-obatan tersebut dalam dosis yang tinggi atau yang dikenal dengan overdosis. Pemakaian sabu-sabu, opium, dan kokain bisa menyebabkan tubuh kejang-kejang dan jika dibiarkan dapat menimbulkan kematian. Inilah akibat fatal yang harus dihadapi jika sampai kecanduan narkotika, nyawa menjadi taruhannya.

\section{- Gangguan Kualitas Hidup}

Bahaya narkoba bukan hanya berdampak buruk bagi kondisi tubuh, penggunaan obat-obatan tersebut juga bisa mempengaruhi kualitas hidup misalnya susah berkonsentrasi saat bekerja, mengalami masalah keuangan, hingga harus berurusan dengan pihak kepolisian jika terbukti melanggar hukum.

Pemakaian zat-zat narkotika hanya diperbolehkan untuk kepentingan medis sesuai dengan pengawasan dokter dan juga untuk keperluan penelitian. Selebihnya, obat-obatan tersebut tidak memberikan dampak positif bagi tubuh. Yang ada, kualitas hidup menjadi terganggu, relasi dengan keluarga kacau, kesehatan menurun, dan yang paling buruk adalah menyebabkan kematian. Karena itu, jangan coba-coba memakai barang berbahaya tersebut karena resikonya sangat tinggi bagi hidup dan kesehatan. 


\section{Pencegahan Penyalahgunaan Narkotika}

Narkotika adalah zat atau obat yang berasal dari tanaman atau bukan tanaman, baik sintetis maupun semisintetis, yang dapat menyebabkan penurunan atau perubahan kesadaran, hilangnya rasa, mengurangi sampai menghilangkan rasa nyeri, dan dapat menimbulkan ketergantungan, yang dibedakan ke dalam golongangolongan sebagaimana terlampir dalam Undang-Undang

Ini (Menurut Pasal 1 ayat (1) Undang-undang Republik Indonesia Nomor 35 Tahun 2009 Tentang Narkotika). Pada perkembangan saat ini, narkotika tidak hanya digunakan dalam bidang farmasi saja, tetapi sudah terjadi penyalahgunaan narkotika. Hal ini sering kali ditemukan pada kalangan remaja hingga masyarakat usia dewasa.

Remaja adalah masa di mana seorang individu mengalami peralihan dari masa anak-anak menuju ke dewasa. Masa remaja disebut masa yang paling rawan dihadapi individu sebagai anak. Dari yang tadinya anak-anak mereka mengalami perkembangan secara fisik maupun psikis dengan beberapa perubahan. Orang tua yang memiliki anak tentu akan menghadapi hal ini di kala membesarkan anak mereka, anak yang beranjak remaja akan mengalami perubahan sesuai dengan pertumbuhan moral seorang anak. Jika kontrol dari orang tua dan orang terdekat anak kurang, maka seringkali terjadi penyimpangan pada anak tersebut. Penyimpangan ini cenderung kearah negatif yang sering disebut dengan kenakalan remaja. Ada banyak jenis kenakalan remaja, seperti perkelahian dan minum-minuman keras, pencurian, perampokan, perusakan/pembakaran, seks bebas bahkan narkoba. Salah satu bentuk kenakalan remaja yang saat ini dapat dikategorikan mengkhawatirkan adalah penyalahgunaan narkoba.

Peredaran dan penyalahgunaan Narkoba merupakan salah satu permasalahan nasional yang dipandang serius oleh pemerintah, karena dapat menyebabkan rusaknya moral bangsa. Karena itu pemerintah sangat memberikan perhatian terhadap penanganan atas penyalahgunaan Narkoba. Di negara kita, masalah merebaknya penyalahgunaan narkoba semakin lama semakin meningkat. Efek domino akibat dari penyalahgunaan narkoba juga semakin beragam, serta usaha untuk mengatasi penyalahgunaan Narkoba merupakan langkah yang tidak mudah untuk dilaksanakan. Penyalah guna adalah orang yang menggunakan Narkotika tanpa hak atau melawan hukum. Ketika seseorang melakukan penyalagunaan Narkotika secara terus-menerus, maka orang tersebut akan berada pada keadaan ketergantungan pada Narkotika, baik secara fisik maupun psikis. Ketergantungan Narkotika adalah kondisi yang ditandai oleh dorongan untuk menggunakan Narkotika secara terus-menerus dengan takaran yang meningkat agar menghasilkan efek yang sama dan apabila penggunaannya dikurangi dan/atau dihentikan secara tiba-tiba, menimbulkan gejala fisik dan psikis yang khas.

Untuk penanggulangan penyalahgunaan narkoba diperlukan upaya yang terpadu dan komprenhensif yang meliputi upaya preventif, represif, terapi dan rehabilitasi Penyebab terjadinya

penyalahgunaan narkoba disebabkan oleh beberapa faktor yang saling mempengaruhi satu sama lain, yaitu: 1) Faktor letak geografi Indonesia; 2) Faktor ekonomi; 3) Faktor kemudahan memperoleh obat; 4) Faktor keluarga dan masyarakat; 5) Faktor kepribadian; 6) Faktor fisik dari individu yang menyalahgunakannya. 


\section{E. Pencegahan Penyalahgunaan Narkoba}

Metode pencegahan dan pemberantasan penyalahgunaan narkoba yang paling efektif dan mendasar adalah metode promotif dan preventif. Upaya yang paling praktis dan nyata adalah represif dan upaya yang manusiawi adalah kuratif serta rehabilitatif.

\section{Promotif}

Program promotif ini kerap disebut juga sebagai program preemtif atau program pembinaan. Pada program ini yang menjadi sasaran pembinaanya adalah para anggota masyarakat yang belum memakai atau bahkan belum mengenal narkoba sama sekali. Prinsip yang dijalani oleh program ini adalah dengan meningkatkan peranan dan kegitanan masyarakat agar kelompok ini menjadi lebih sejahtera secara nyata sehingga mereka sama sekali tidak akan pernah berpikir untuk memperoleh kebahagiaan dengan cara menggunakan narkoba. Bentuk program yang ditawrkan antara lain pelatihan, dialog interaktif dan lainnya pada kelompok belajar, kelompok olah raga, seni budaya, atau kelompok usaha. Pelaku program yang sebenarnya paling tepat adalah lembaga-lembaga masyarakat yang difasilitasi dan diawasi oleh pemerintah.

\section{Preventif}

Program promotif ini disebut juga sebagai program pencegahan dimana program ini ditujukan kepada masyarakat sehat yang sama sekali belum pernah mengenal narkoba agar mereka mengetahui tentang seluk beluk narkoba sehingga mereka menjadi tidak tertarik untuk menyalahgunakannya. Program ini selain dilakukan oleh pemerintah, juga sangat efektif apabila dibantu oleh sebuah instansi dan institusi lain termasuk lembaga-lembaga profesional terkait, lembaga swadaya masyarakat, perkumpulan, organisasi masyarakat dan lainnya. Bentuk dan agenda kegiatan dalam program preventif ini:

a. Kampanye anti penyalahgunaan narkoba

Program pemberian informasi satu arah dari pembicara kepada pendengar tentang bahaya penyalahgunaan narkoba. Kampanye ini hanya memberikan informasi saja kepada para pendengarnya, tanpa disertai sesi tanya jawab. Biasanya yang dipaparkan oleh pembicara hanyalah garis besarnya saja dan bersifat informasi umum.Informasi ini biasa disampaikan oleh para tokoh asyarakat.Kampanye ini juga dapat dilakukan melalui spanduk poster atau baliho.Pesan yang ingin disampaikan hanyalah sebatas arahan agar menjauhi penyalahgunan narkoba tanpa merinci lebih dala mengenai narkoba.

b. Penyuluhan seluk beluk narkoba Berbeda dengan kampanye yang hanya bersifat memberikan informasi, pada penyuluhan ini lebih bersifat dialog yang disertai dengan sesi tanya jawab. Bentuknya bisa berupa seminar atau ceramah.Tujuan penyuluhan ini adalah untuk mendalami pelbagai masalah tentang narkoba sehingga masyarakat menjadi lebih tahu karenanya dan menjadi tidak tertarik enggunakannya selepas mengikuti program ini. Materi dalam program ini biasa disampaikan oleh tenaga profesional seperti dokter, psikolog, polisi, ahli hukum ataupun sosiolog sesuai dengan tema penyuluhannya. 


\section{c. Pendidikan dan pelatihan kelompok sebaya}

Perlu dilakukan pendidikan dan pelatihan didalam kelompok masyarakat agar upaya menanggulangi penyalahgunaan narkoba didalam masyarakat ini menjadi lebih efektif. Pada program ini pengenalan narkoba akan dibahas lebih mendalam yang nantinya akan disertai dengan simulasi penanggulangan, termasuk latihan pidato, latihan diskusi dan latihan menolong penderita. Program ini biasa dilakukan dilebaga pendidikan seperti sekolah atau kampus dan melibatkan narasumber dan pelatih yang bersifat tenaga profesional.

d. Upaya mengawasi dan mengendalikan produksi dan upaya distribusi narkoba di masyarakat.

Pada program ini sudah menjadi tugas bagi para aparat terkait seperti polisi, Departemen Kesehatan, Balai Pengawasan Obat dan Makanan (BPOM), Imigrasi, Bea Cukai, Kejaksaan, Pengadilan dan sebagainya. Tujuannya adalah agar narkoba dan bahan pembuatnya tidak beredar sembarangan didalam masyarakat namun melihat keterbatasan jumlah dan kemampuan petugas, program ini masih belum dapat berjalan optimal.

\section{Kuratif}

Program ini juga dikenal dengan program pengobatan dimana program ini ditujukan kepada para peakai narkoba.Tujuan dari program ini adalah mebantu mengobati ketergantungan dan menyembuhkan penyakit sebagai akibat dari pemakaian narkoba, sekaligus menghentikan peakaian narkoba.Tidak sembarang pihak dapat mengobati pemakai narkoba ini, hanya dokter yang telah mempelajari narkoba secara khususlah yang diperbolehkan mengobati dan menyembuhkan pemakai narkoba ini.Pngobatan ini sangat rumit dan dibutuhkan kesabaran dala menjalaninya.Kunci keberhasilan pengobatan ini adalah kerjasama yang baik antara dokter, pasien dan keluarganya.

Bentuk kegiatan yang yang dilakukan dalam program pengobat ini adalah:

a) Penghentian secara langsung;

b)Pengobatan gangguan kesehatan akibat dari penghentian dan pemakaian narkoba (detoksifikasi);

c) Pengobatan terhadap kerusakan organ tubuh akibat pemakaian narkoba;

d) Pengobatan terhadap penyakit lain yang dapat masuk bersama narkoba seperti HIV/AIDS, Hepatitis B/C, sifilis dan lainnya. Pengobatan ini sangat kompleks dan memerlukan biaya yang sangat mahal. Selain itu tingkat kesembuhan dari pengobatan ini tidaklah besar karena keberhasilan penghentian penyalahgunaan narkoba ini tergantung ada jenis narkoba yang dipakai, kurun waktu yang dipakai sewaktu menggunakan narkoba, dosis yang dipakai, kesadaran penderita, sikap keluarga penderita dan hubungan penderita dengan sindikat pengedar.

Selain itu ancaman penyakit lainnya seperti HIV/AIDS juga ikut mempengaruhi, walaupun bisa sembuh dari ketergantungan narkoba tapi apabila terjangkit penyakit seperti AIDS tentu juga tidak 
dapat dikatakan berhasil.

\section{Rehabilitatif}

Program ini disebut juga sebagai upaya pemulihan kesehatan jiwa dan raga yang ditujukan kepada penderita narkoba yang telah lama menjalani program kuratif. Tujuannya agar ia tidak memakai

dan bisa bebas dari penyakit yang ikut menggerogotinya karena bekas pemakaian narkoba. Kerusakan fisik, kerusakan mental dan penyakit bawaan macam HIV/AIDS biasanya ikut menghampiri para pemakai narkoba. Itulah sebabnya mengapa pengobatan narkoba tanpa program rehabilitasi tidaklah bermanfaat. Setelah sembuh masih banyak masalah yang harus dihadapi oleh bekas pemakai tersebut, yang terburuk adalah para penderita akan merasa putus asa setelah dirinya tahu telah terjangit penyakit macam HIV/AIDS dan lebih memilih untuk mengakhiri dirinya sendiri. Cara yang paling banyak dilakukan dalam upaya bunuh diri ini adalah dengan cara menyuntikkan dosis obat dalam jumlah berlebihan yang mengakibatkan pemakai mengalami Over Dosis (OD). Cara lain yang biasa digunakan untuk bunuh diri dalah dengan melompat dari ketinggian, membenturkan kepala ke tembok atau sengaja melempar dirinya untuk ditbrakkan pada kendaraaan yang sedang lewat. Banyak upaya pemulihan namun keberhasilannya sendiri sangat bergantung pada sikap profesionalisme lembaga yang menangani program rehabilitasi ini, kesadaran dan kesungguhan penderita untuk sembuh serta dukungan kerja sama antara penderita, keluarga dan lembaga.

Masalah yang paling sering timbul dan sulit sekali untuk dihilangkan adalah mencegah datingnya

kembali kambuh (relaps) setelah penderita menjalani pengobatan. Relaps ini disebabkan oleh keinginan kuat akibat salah satu sifat narkoba yang bernama habitual.Cara yang paling efektif untuk menangani hal ini adalah dengan melakukan rehabilitasi secara mental dan fisik.Untuk pemakaipsikotropika biaanya tingkat keberhasilan setlah pengobatan terbilang sering berhasil, bahkan ada yang bisa sembuh 100 persen.

\section{Represif}

Ini merupakan program yang ditujukan untuk menindak para produsen, bandar, pengedar dan

pemakai narkoba secara hukum.Program ini merupakan instansi peerintah yang berkewajiban

mengawasi dan mengendalikan produksi aupun distribusi narkoba.Selain itu juga berupa penindakan terhadap pemakai yang melanggar undang-undang tentang narkoba. Instansi yang terkain dengan program ini antara lain polisi, Departemen Kesehatan, Balai Pengawasan Obat dan Makanan (BPOM), Imigrasi, Bea Cukai, Kejaksaan, Pengadilan. Begitu luasnya jangkauan peredaran gelap narkoba ini tentu diharapkan peran serta masyarakat, termasuk LSM dan lembaga kemasyarakatan lain untuk berpartisipasi membantu para aparat terkait tersebut Masyarakat juga harus berpartisipasi, paling tidak melaporkan segala hal yang berhubungan dengan kegiatan yang terkait dengan penyalahgunaan narkoba dilingkungannya. Untuk memudahkan partisipasi masyarakat tersebut, polisi harus ikut aktif menggalakkan pesan dan ajakan untuk melapor ke polisi bila melihat kegiatan penyalahgunaan narkoba.Cantumkan pula 
nomor dan alamat yang bisa dihubungi sehingga masyarakat tidak kebingungan bila hendak melapor.

Melaporkan kegiatan pelanggaran narkoba seperti ini tentu saja secara tidak langsung ikut mebahayakan keselamatan si pelapor, karena sindikat narkoba tentu tak ingin kegiatan mereka terlacak dan diketahui oleh aparat. Karena itu sudah jadi tugas polisi untuk melindungi keselamatan jiwa si pelapor dan merahasiakan identitasnya. Masalah penyalahgunaan narkoba adalah masalah yang kompleks yang pada umumnya disebabkan oleh tiga faktor yaitu: faktor individu, faktor lingkungan/sosial dan faktor ketersediaan, menunjukkan bahwa pencegahan penyalahgunaan narkoba yang efektif memerlukan pendekatan secara terpadu dan komprehensif. Pendekatan apa pun yang dilakukan tanpa mempertimbangkan ketiga faktor tersebut akan mubazir. Oleh karena itu peranan semua sektor terkait termasuk para orangtua, guru, tokoh masyarakat, tokoh agama, kelompok remaja dan LSM di masyarakat, dalam pencegahan narkoba sangat penting.

1. Peran remaja

a. Pelatihan keterampilan.

b. Kegiatan alternatif untuk mengisi waktu luang seperti : kegiatan olahraga, kesenian dan lainlain.

2. Peran orangtua

a. Menciptakan rumah yang sehat, serasi, harmonis, cinta, kasih saying dan komunikasi terbuka.

b. Mengasuh, mendidik anak yang baik.

c. Menjadi contoh yang baik.

d. Mengikuti jaringan orang tua.

e. Menyusun peraturan keluarga tentang keluarga bebas narkoba.

f. Menjadi pengawas yang baik.

3. Peran Tokoh Masyarakat

a. Mengikutsertakan dalam pengawasan narkoba dan pelaksanaan Undang-undang.

b. Mengadakan penyuluhan, kampanye pencegahan penyalahgunaan narkoba.

c. Merujuk korban narkoba ke tempat pengobatan.

d. Merencanakan, melaksanakan dan mengkoordinir program-program pencegahan penyalahgunaan narkoba. 
Masyarakat mempunyai peran penting didalam usaha pencegahan dan penanggulangan penyalahgunaan narkoba. Untuk itu tokoh masyarakat dapat melaksanakan hal-hal sebagai berikut :

1) Pahami masalah penyalahgunaan narkoba, pencegahan dan penanggulangannya.

2) Amati situasi dan kondisi lingkungan.

3) Galang potensi masyarakat yang dapat membantu pelaksanaan penanggulangannya, terutama orangtua, para remaja, sekolah, organisasi-organisasi sosial dalam masyarakat di sekitar lingkungan.

4) Arahkan, dorong dan kendalikan gerakan masyarakat tersebut.

Cara menggerakkan masyarakat dengan tahap-tahap sebagai berikut :

1) Tatap muka dan berbicara secara terbuka maksud gerakan tersebut.

2) Adakan rapat untuk menyusun program kerja.

3) Libatkan tokoh-tokoh masyarakat, organisasi sosial, tokoh agama dan potensi-potensi masyarakat yang ada.

4) Beri pengertian tentang masalah penyalahgunaan narkoba dimana masalah tersebut bukan hanya menjadi tanggungjawab pemerintah tapi juga masyarakat. Adapun strategi pencegahan penyalahgunaan narkoba di masyarakat dapat dilakukan melalui langkah-langkah sebagai berikut.

a. Pelatihan dan Pendidikan

Merencanakan dan melaksanakan kursus pelatihan untuk berbagai kelompok masyarakat seperti orang tua, tokoh-tokoh masyarakat, kelompok remaja tentang strategi-strategi pencegahan, keterampilan mengasuh anak, pelatihan kerja untuk anak-anak remaja dan lainlain.

b. Kebijakan dan Peraturan

Masyarakat perlu menyusun kebijakan dan peraturan tentang penanggulangan dan pencegahan narkoba dan zat adiktif lainnya.

\section{c. Kegiatan Kemasyarakatan}

Tokoh-tokoh masyarakat dapat mendorong dan menggerakkan masyarakat terutama para remaja untuk bergiat dalam kegiatan-kegiatan yang positif fan kegiatan kemasyarakatan seperti kerja bakti, pemeliharaan kebersihan, kesehatan, dan penghijauan lingkungan.

\section{d. Promosi Hidup Sehat}

Tokoh-tokoh masyarakat dapat menyusun program-program yang mengutamakan pada pengembangan hidup sehat seperti : gerak jalan, lomba olahraga, senam bersama, rekreasi bersama, dll. 


\section{e. Sistem Rujukan}

Tokoh-tokoh masyarakat bisa membantu mereka yang rawan atau yang korban narkoba untuk mendapatkan pelayanan pengobatan, perawatan atau rehabilitasi sosial melalui sistem rujukan atau tata cara yang disepakati.

f. Pembentukan Kelompok Konseling Pembentukan kelompok konseling dari warga masyarakat, tokoh-tokoh masyarakat atau organisasi sosial masyarakat, sebagai relawan untuk memberikan konsultasi/konseling kepada warga atau remaja-remaja yang memiliki masalah pribadi atau memiliki kerawanan atau telah menjadi korban narkoba.

\section{g. Organisasi}

Penetapan prosedur hubungan kerjasama antara organisasi sosial masyarakat yang satu dengan yang lainnya dan dengan tokoh-tokoh masyarakat formal/informal sangat penting untuk memperlancar dan meningkatkan koordinasi dalam penanggulangan dan pencegahan penyalahgunaan narkoba di lingkungannya. Di daerah yang kena wabah narkoba, akibatnya sudah amat jelas.Selain orang yang terkena narkoba menjadi tidak produktif, kehadirannya amat membebani bahkan menghancurkan kehidupan keluarga, mengancam keamanan lingkungan, dan

memicu aksi-aksi kejahatan di masyarakat. Keadaan buruk ini sudah menimbulkan masyarakat benar-benar cemas dan merasa muak dan masyarakat sudah mulai perang melawan narkoba.

Pengalaman pencegahan penyalahgunaan narkoba diluar dan didalam negeri menunjukkan bahwa pencegahan penyalahgunaan narkoba yang fektif memerlukan peranan aktif dari segenap lapisan

masyarakat termasuk para orang tua, tokoh masyarakat dan agama, kelompok remaja dan kelompok masyarakat lainnya. Partisipasi dan kolaborasi oleh segenap lapisan masyarakat adalah strategi yang sangat diperlukan untuk merespon secara multi disiplin pada permasalahan penyalahgunaan narkoba yang sangat kompleks.Kita menyadari bahwa permasalahan penyalahgunaan narkoba merupakan hasil interaksi berbagai faktor seperti tersedianyanarkoba sendiri aspek kepribadian dan perilaku individu.

Dengan kenyataan ini, sepertinya tidak ada satu sistem atau kelompok pun yang bisa memberantas dan mencegah sendiri penyalahgunaan narkoba dilingkungannya. Pemerintah saja tidak dapat mengatasi masalah narkoba tersendiri.Masalah penyalahgunaan narkoba yang sangat kompleksi ini tetap menuntut penanganan secara komprehensif dan terpadu, dengan partisipasi aktif dari masyarakat baik secara individu maupun kelompok yang mempunyai potensi membantu generasi muda mencegah penyalahgunaan narkoba. 


\section{BAB III \\ PENUTUP}

\section{A. Kesimpulan}

Kebiasaan menggunakan narkoba di kalangan remaja amat membahayakan baik ditinjau dari segi pendidikan maupun kesehatan serta social ekonomi. Dipandang dari segi pendidikan sudah jelas bahwa hal ini akan mengganggu pelajarannya, sedangkan dari segi kesehatan akibat kebiasaan menggunakan narkoba akan menyebabkan berbagai penyakit. Melalui sikap kepedulian, pencegahan berbagai tindak criminal, kenakalan remaja, keamanan, kedamaian, keharmonisan, akan mudah dicipatakan. Dengan sikap kepedulian ini, maka motto bahwa, "Mencegah lebih baik dari mengobati" akan benar benar terbukti. Pada tahap awal kehidupan manusia agen sosialisasi pertama adalah keluarga. Oleh karena itu, orang tua merupakan orang penting dalam hal ini. Guna mencegah terjerumusnya para penerus bangsa tersebut ke dunia nakoba, maka campur tangan dan tanggung jawab orang tua memegang peranan penting disini, karena baik atau buruknya perilaku anak sangat bergantung bagaimana orang tua menjadi teladan bagi putra-putrinya.

\section{B. Saran}

Semoga kita senantiasa terhindar dari bahaya narkoba, mari kita isi waktu luang dengan kegiatan bermanfaat yang dapat meningkatkan kualitas diri kita. Seperti berolahraga, belajar, dan lain sebgainya.

Dengan demikian berarti kita dapat menjadi anak yang berbakti kepada kedua orangtua, dengan senantiasa berusaha sekuat tenaga membahagiakan mereka. Dengan membahagiakan mereka tanpa disadari kita telah membuka pintu kemudahan dan kesuksesan bagi diri kita sendiri di masa yang akan datang. Salah satunya dengan cara tidak mencoba narkoba walaupun itu hanya sedikit.

Perlunya peran dari orang tua yang harus memperhatikan anaknya agar tidak terjerumus ke dalam jurang narkoba. Disamping itu perlu kerja sama antar masyarakat dengan aparat untuk memeberantas peredaran narkoba. Remaja harus diperhatikan oleh semua pihak agar tidak terjerumus pada penyalahgunaan narkoba itu sendiri. 


\section{DAFTAR PUSAKA}

https://bnn.go.id/pengertian-narkoba-dan-bahaya-narkoba-bagi-kesehatan/

http://pn-karanganyar.go.id/main/index.php/berita/artikel/997-pencegahan-penyalahgunaan-narkotika 